Aslan-Açan, B. ve Özbesler, C. (2020). Farklı Sosyal Hizmet Kurumlarında Çalışan Sosyal Hizmet Uzmanlarının İş Doyumu ve Tükenmişlik Düzeylerinin Değerlendirilmesi. Toplum ve Sosyal Hizmet, 31(1), 106-130.

Araştırma

\title{
FARKLI SOSYAL HIZMET KURUMLARINDA ÇALIŞAN SOSYAL HIZMET UZMANLARININ ISŞ DOYUMU VE TÜKENMIŞLIK DÜZEYLERINININ DEĞERLENDIRILMESI ${ }^{1}$
}

Evaluation of Job Satisfaction and Burnout Levels of Social Workers Working in Different Social Services

\author{
Bilge ASLAN AÇAN* \\ Cengiz ÖZBESLER** \\ * Öğr. Gör. Üsküdar Üniversitesi, Sağlık Hizmetleri Meslek Yüksek Okulu, Sosyal Hizmet Bölümü, \\ bilge_as1@hotmail.com, ORCID ID: 0000-0003-4030-655X \\ ** Prof. Dr. Ankara Yıldırım Beyazıt Üniversitesi, Sağlık Bilimleri Fakültesi, Sosyal Hizmet Bölümü, \\ ozbesler@gmail.com, ORCID ID: 0000-0002-1397-6913
}

\section{ÖZET}

$\mathrm{Bu}$ araştırma, farklı sosyal hizmet kurumlarında çalışan sosyal hizmet uzmanlarının iş doyumu ve tükenmişlik düzeylerini tespit etmek amacıyla gerçekleştirilmiştir. Tarama modelinde bir nicel araştırma olarak planlanan bu araştırmanın çalışma evrenini çalışmanın yapıldığı tarihlerde İstanbul ilinde görev yapmakta olan tüm sosyal hizmet uzmanları oluşturmaktadır. Verilerin elde edilmesinde araştırmacı tarafından hazırlanmış olan bir kişisel bilgi formu, Minnesota iş doyum Ölçeği ve Maslach tükenmişlik Ölçeği kullanılmıştır. Elde edilen bulgular, $t$ testi ve Anavo analizi sonuçlarına dayalı olarak yorumlanmış, verilerin analizi aşamasında SPSS 21 programı kullanılmıştır. Çalışmanın bulgularına göre haftalık 20-30 saat müracaatçılarla birebir çalışanlarda dışsal doyum puanlarının yüksek, 5-10 yıl kıdeme sahip olan çalışanların içsel doyum puanlarının yüksek olduğu tespit edilmiştir. Mesleği isteyerek seçenler ile kendini mesleki olarak yeterli hissedenlerin içsel ve dişsal doyum puanlarının daha yüksek olduğu belirlenlmiştir. Sosyal hizmet uzmanlarının kendini yetersiz hissettikçe duygusal tükenmişlik ve düşük kişisel başarı puanı azalmakta, yeterli hissettikçe içsel ve dışsal doyum puanı yükselmektedir. Ayrıca iş arkadaşları ile iletişim

\footnotetext{
${ }^{1}$ Bu çalışma Farkli Sosyal Hizmet Kurumlarinda Çalişan Sosyal Hizmet Uzmanlarinin Iş Doyumu Ve Tükenmişlik Düzeylerininin Değerlendirilmesi adlı yüksek lisans tezinin bir bölümünden oluşmaktadır.
} 
kalitesi azaldıkça duygusal tükenmişlik puanları, yöneticileri ile iletişim kalitesi azaldıkça ise tükenmişlik boyutları puanları azalmaktadır.

Iş arkadaşları ve yönetici ile iletişim kalitesi arttıkça da içsel ve dışsal doyum puanı artmaktadır. Kurum içerisinde ise bağımsız karar verme süreci desteklenmedikçe duygusal tükenmişlik, duyarsızlaşma ve düşük kişisel başarı puanı desteklendikçe de içsel ve dışsal doyum puanı artmaktadır.Bu çalışmadan elde edilen araştırma bulgularının sosyal hizmet uzmanlarının iş doyumu ve tükenmişlik düzeylerini etkileyen değişkenlerin belirlenerek uzmanların işlerinde verimli ve başarılı olmalarına katkıda bulunması bakımından önem arz edeceği düşünülmektedir.

Anahtar Kelimeler: Iş Doyumu, Sosyal hizmet uzmanı, Tükenmişlik

\begin{abstract}
The aim of this research was to determine the job satisfaction and burnout levels of social workers working in different social services. This study which was planned as a quantitative research in general survey model has a target population that consists of all social workers working in Istanbul. During the procurement of the data, Personal information form created by the researcher, Minnesota Job Satisfaction Scale and Maslach Burnout Scale were used. The acquired findings of the survey were interpreted based on the results of the t-test and Anavo analysis, and the data were analyzed in the SPSS 21 program. As a result of the findings of the study, it was determined that the employees working one to one with clients have more than 20-30 hours higher internal satisfaction scores and those with seniority of 510 years have higher internal satisfaction scores. It was determined that those who willingly chose the profession and those who felt themselves professionally had higher internal and external satisfaction scores. Emotional exhaustion and low personal success points decrease, internal and external satisfaction scores are increased as social workers feel inadequate. In addition, as the quality of communication decreases, the emotional exhaustion degree and the quality of communication with the managers decreases as the burnout dimension scores and the quality of communication with colleagues and manager increases and the internal and external satisfaction scores increase. Emotional exhaustion, depersonalization and low personal accomplishment score, and internal and external satisfaction scores are increased as long as independent decision-making process is not supported within the organization. It is thought that the research findings obtained from this study will determine the variables affecting the satisfaction and burnout levels of the social workers and will be important in terms of contributing to the overall efficiency and success.
\end{abstract}

Keywords: Burnout, Job Satisfaction, Social work

\title{
GíRiş
}

Tükenmişlik genel tanımıyla bireyin çalıştığı iş yerinde duygusal, fiziksel ve zihinsel olarak tükenmesi olarak belirtilmektedir (Figley, 1995). Sosyal hizmet uzmanları tükenmişlik sendromuna diğer meslek gruplarına oranla daha yüksek düzeyde maruz kalmakta ve bunun sonucunda ortalamanın üzerinde fiziksel ve zihinsel problemler yaşamaktadırlar (Anderson ve Lundberg, 2008,). Sosyal hizmet uzmanları çalıştıkları vakalardan ve bu süreçte karşılaştıkları duygusal gerginliklerden dolayı tükenmişlik ve şevkat yorgunluğuna karşı savunmasız kalmaktadırlar. Uzmanlar genel olarak çalışma hayatında iş yükü, çalışılan vaka sayısının fazlalığı, vaka yönetimi ile geçirilen uzun zamanlar, iş arkadaşları ve 
yönetici ile yaşanan çatışmalar gibi sorunlar yaşamaktadırlar (Choı, 2010). Bell ve diğ. (2003) de buna benzer olarak uzmanların ağır iş yükü, zaman baskısı, kurumların yoğun talepleri, kaynak eksiklikleri, yöneticiden gelen desteğin yetersiz kalması gibi problemler yaşadıklarını belirtmiştir. Birçok sosyal hizmet uzmanı, belirli bir zamanda 20 ila 50 vakayı yöneterek her bir vaka için çocukların ve ailelerin refahını etkileyen hayati kararlar vermektedirler (Pecora ve diğ., 2000). Bazı zamanlarda da incemelerinde ve görüşmelerinde kendilerini tehlikeli ortamlarda bulmaktadırlar (Mackie, 2005). Çoğu zaman hizmet verdikleri gruplar; ciddi zihinsel ve sosyal problemleri olan insanlar, suça karışmış bireyler, doğal afet, ihmal ve istismar, işkence, soykırım ve savaş mağdurları gibi travma yaşamış müracaatçılardan oluşmaktadır. Dezavantajlı gruplarla çalışmak, rol çatışmaları, kaynakların yetersizliği, değerlendirme kriterlerinin yetersiz kalması gibi karşılaşılan birçok olumsuz durum uzmanlarda fiziksel, duygusal ve zihinsel tükenmeye sebep olmaktadır.

Sosyal hizmet uzmanları uygulamalarını ilgili yasa ve polikalar çerçevesinde gerçekleştirmektedir. Bu nedenle uzmanlar, müdahalelerinde çoğu zaman müracaatçılar için en uygun olan kararı vermektense politika ve prosedürlerlere uygun olacak şekilde hareket etmek durumunda kalmaktadırlar. Böylece uzmanlar zamanla pasif ve bağımlı hareket ederek, sistem tarafından öngörülen talimatları izlemeyi öğrenmektedirler (Bell ve diğ., 2003). Bürokratik işlemleri de içeren bu süreç sonucunda uzmanlar işleri üzerindeki kontrollerini yitirmekte ve otonominin gelişmediği duygusunu yaşamaktadırlar. Bunun sonucunda belirlenen hedefe ulaşamadığını ve müracaatçılarının beklentileri karşılayamadığını düşünen uzmanlar yetersiz olduklarını hissebilmektedirler. Böylece çalışma istekleri de azalabilmektedir. Bu duruma paralel olarak da iş doyumsuzluğunda (Mackie, 2005) ve uzmanların yaşadığı etik ikilemlerde artış görülmektedir (Arches, 1991).

Sosyal hizmet uzmanlarının mesleki rolleri müracaatçıların ihtiyaçları doğrultusunda şekillenmekte, müracaatçı merkezli müdahaleler ekseninde gerçekleşmektedir. Ayrıca uzmanlar bu müdahaleleri gerçekleştirirken empati becerisini kullanarak mesleki ilişkilerini kurmaktadırlar. Kurulan bu empatik ilişki sonucunda müracaatçıların karşılaştıkları problemler sosyal hizmet uzmanının çözmesi gereken problemler haline gelmektedir (Bride ve diğ., 2007) ve bu durum uzmanlarda ikincil travmaların da oluşumuna sebep olmaktadır. Ayrıca uzmanlar bu süreçte kendi intiyaçlarını ve strese yönelik verdikleri tepkilerini göz ardı etmektedirler (Figley, 1995). Strese bu denli maruz kalma sonucunda ise bireyde çevresine ve iş 
yaşamına yönelik ilgisiz ve kayıtsız davranışlar baş gösterebilmektedir. Bu gibi birçok durum uzmanların değerlendirmelerini olumsuz etkilemekte ve etkisiz müdahale planları oluşturmalarına neden olabilmektedir (Williams ve Sommer, 1995). Profesyoneller için, bu aksamalar, duygusal bağııık ve yakınlık kaybına (örneğin; aile ve arkadaşlar) neden olarak, benlik saygısını da azaltmaktadır (Saakvitne, 1996). Bu tükenmişlik durumu kurumlara ve çalışanlara olumsuz sonuçlar doğurmaktadır. Tükenmişlik düzeyi yüksek olan çalışanlar zamanla kendilerini iş yaşamından soyutlayarak, müracaatçılarına gereken özen ve ilgiyi göstermemektedirler. Böylece uzmanlar işinin gerektirdiği görevleri yerine getirememekte ve kritik kararları vermekte zorluk yaşamaktadırlar. Böylece kuruma ve müracaatçılara telafisi mümkün olmayan sorunlar yaratabilmektedirler. Dolayısı ile tükenmişliğin artışına sebebiyet veren durumların tespit edilmesi ve önlenmesi büyük önem arz etmektedir. Tükenmişliğin oluşmasının en büyük sebeplerden biri iş doyumsuzluğudur. Bu sebeple tükenmişliğin önlenmesi iş doyumunun sağlanması ile mümkün olabilmektedir. Bu doğrultuda sosyal hizmet uzmanlarının iş doyum düzeylerinin saptanması, tükenmişlik sebeplerinin araştırılması ve doyumsuz oldukları durumların belirlenerek, intiyaçların belirlenmesi ve bu konuda önlemler alınması gerekmektedir. Literatür incelendiğinde iş doyumu ve tükenmişlik düzeyinin ilişkisini inceleyen araştırmanın olduğu ancak iş doyumu ve tükenmişlik düzeylerinin birçok farklı değişkenlerle olan ilişkisini inceleyen çalışmaların çok az olduğu görülmüştür. Çoğu araştırmada sosyal hizmet uzmanlarının yaş, çaşılan kurum ve kıdem durumları gibi belli değişkenler ele alınmıştır. Bu çalışmada bu değişkenlere ek olarak; haftalık çalışma saati, mesleği isteyerek seçip seçmemek, mesleki açıdan yeterli hissedip hissetmeme, müracaatçılara yeterli hizmet verilip verilmemesi, yönetici ve iş arkadaşları ile olan iletişim ve çalışılan kurumda bağımsız karar verme davranışının desteklenip desteklenmediği ele alınmıştır. Bu sebeple bu araştırmanın sosyal hizmet uzmanlarının tükenmişlik düzeylerinin belirlenmesinin yanında, tükenmişliğe etki eden değişkenlerin belirlenmesi ve sorunlarının daha iyi anlaşılmasını sağlanacağı düşünülmektedir. Ayrıca belirlenen bu sorunlara çözüm önerilerinde bulunularak, uzmanların mesleklerinde daha etkili ve başarılı hizmet sunmalarına katkıda bulunmak bakımından önem arz edeceği ve daha sonra yapılacak çalışmalara örnek teşkil etmesi beklenmektedir.

$\mathrm{Bu}$ araştırmanın genel amacı farklı sosyal hizmet kurumlarında çalışan sosyal hizmet uzmanlarının iş doyumu ve tükenmişlik düzeylerini tespit etmek ve bazı demografik değişkenlere göre farklılaşıp farklılaşmadığını tespit etmektir. 
Bu amaca dayalı olarak aşağıda belirtilen araştırma soruları oluşturulmuştur.

1. Sosyal hizmet uzmanlarının iş doyumları ile tükenmişlik düzeyleri arasında nasıl bir ilişki vardır?

2. Sosyal hizmet uzmanlarının iş doyumları ile tükenmişlik düzeyleri demografik değişkenlere göre farklılaşmakta mıdır?

\section{YÖNTEM}

$\mathrm{Bu}$ çalışma, tarama modelinde bir nicel araştırma olarak planlanmıştır. Tarama modelleri, geçmişte ya da halen var olan bir durumu var olduğu şekliyle betimlemeyi amaçlayan araştırma yaklaşımıdır. Araştırmaya konu olan olay, birey ya da nesne, kendi koşulları içinde ve olduğu gibi tanımlanmaya çalışılır. Onları herhangi bir şekilde değiştirme, etkileme çabası gösterilmez. Bilinmek istenen şey vardır ve oradadır (Karasar, 2002: 77).

$\mathrm{Bu}$ araştırmada kullanılan tarama modeli, genel tarama modelidir. Genel tarama modelleri, çok sayıda elemandan meydana gelen bir evrende, evren hakkında genel bir sonuca varmak amacıyla evrenin tamamı ya da ondan alınacak bir grup örnek ya da örneklem üzerinde yapılan tarama düzenlemeleridir (Karasar, 2006: 79).

\section{Evren ve Çalışma Grubu}

Bu araştırmanın çalışma evrenini çalışmanın yürütüldüğü tarihlerde İstanbul ilinde görev yapmakta olan tüm sosyal hizmet uzmanları oluşturmaktadır. Bu çalışmada 'Tam Sayım Yöntemi' kullanılmış, ancak iş yoğunluğu, doğum veya askerlik izinleri, yıllık izinler ve ankete katılmayı kabul etmemelerinden dolayı araştırmaya katılmayı kabul eden 152 sosyal hizmet uzmanına anket uygulanmıştır. Katılımcıların 94'ü (\%61.8) kadın, 58'i (\%38.2) erkektir. 79'u (\%52.0) 30 yaş ve altı, 42'si (\%27.6) 31-40 yaş, 22'si (\%14.5) 41-50 yaş ve 9'u $(\% 5,9) 51$ yaş ve üstü yaş aralığındadır. 102'sinin (\%67.1) lisans, 44'ünün (\%28.9) yüksek lisans, 6'sının (\%3.9) doktora mezunu olduğu, katılımcıların 90'ının (\%59.2) ASPB'de, 20'sinin (\%13.2) Adalet Bakanlığında, 17'sinin (\%11.2) belediyede, 21'inin (\%13.8) Sağlık Bakanlığında, 2'sinin (\%1.3) KYK'da, 123'ünün (\%80.9) kamu kurumunda, 28'inin (\%18.4) özel kurumda çalışmakta olduğu tespit edilmiştir.

\section{Veri Toplama Araçları}


Çalışmada çalışanların tükenmişlik düzeyinin tespiti için Maslach Tükenmişlik Ölçeği, iş doyumlarının ölçülmesi için Minnesota Doyum Ölçeği, kişisel bilgileri için ise kişisel bilgi formu"ndan yararlanılmıştır.

Kişisel bilgi formunda yaş, çaşılan kurum ve kıdem durumları, haftalık çalışma saati, mesleği isteyerek seçip seçmeme durumu, mesleki açıdan yeterli hissedip hissetmeme, müracaatçılara yeterli hizmet verilip verilmemesi, yönetici ve iş arkadaşları ile olan iletişim ve çalışılan kurumda bağımsız karar verme davranışının desteklenip desteklenmediği hakkında bilgi toplamaya yönelik sorular sorulmuştur. Kişisel bilgi formunun hazırlanmasında İçağasıoğlu-Çoban ve Özbesler (2016) ve Calitz ve diğ. (2014) 'in çalışmalarından yaralanıımıştır.

İş doyumunun ölçümünü gerçekleştirmek amacıyla Weiss vd. (1967) tarafından geliştirilen Minnesota İş Doyum Ölçeği kullanıımıştır. Ölçeğin Türkçeye çevrilmesi ile geçerlilik ve güvenlik çalışmasını Baycan (1985) yapmıştır (Cronbach alfa =0,77).

Minnesota İş Doyum Ölçeği 1-5 arasında puanlanan beşli likert tipi bir ölçektir. Ölçek puanlamasında, Hiç memnun değilim; 1 puan, Memnun değilim; 2 puan, Kararsızım; 3 puan, Memnunum; 4 puan, Çok memnunum; 5 puan olarak değerlendirilmektedir. Ölçek 5'li likert tipinden oluşmaktadır. Minnesota İş Doyum Ölçeği; genel doyum, içsel ve dışşal doyum düzeylerinin tespitini amaçlayan toplam 20 maddeyi içermektedir. İçsel doyumu 1, 2, 3, 4, 7, 8, 9, 10, 11, 15, 16, 20, dışsal doyumu 5, 6, $12,13,14,17,18,19$, genel doyumu $1,2,3,4,5,6,7,8,9,10,11,12,13,14,15$, $16,17,18,19,20$ maddeleri karşılamaktadır. Ölçekte ters madde bulunmamaktadır.

Genel doyum puanı 20 maddeden elde edilen puanların toplamının 20' ye, içsel doyum puanı içsel faktörleri oluşturan maddelerden elde edilen puanların toplamının 12 ' ye, dışsal doyum puanı ise dışsal faktörleri oluşturan maddelerden elde edilen puanların toplamının 8'e bölünmesiyle elde edilmektedir. Ölçeğin nötr doyum puanı 3' tür. Ölçekten alınan puan 3' ten küçük ise iş doyumu düşük, 3'ten büyük ise iş doyumu yüksek olarak değerlendirilmektedir.

Araştırmada kullanılan ikinci ölçek Maslach Tükenmişlik Ölçeğidir. Ölçek Maslach ve Jackson (1981) tarafından geliştirilmiştir. Ergin (1992) tarafından Türkçe çevirisi, geçerlilik ve güvenilirlik çalışmaları yapılmıştır. Ölçek, beşli likert tipindedir. Puanlama 1-5 arasında yapılmıştır. Ölçek puanlamasında hiçbir zaman (1), çok nadir (2), bazen (3), çoğu zaman (4), her zaman (5) olarak değerlendirmektedir. 
Ölçekte üç boyut ve 22 madde bulunmaktadır. Duygusal tükenme, kişisel başarı ve duyarsızlaşma boyutunda sırası ile 9,8 ve 5 madde yer almaktadır. Duygusal tükenme boyutu; 1, 2, 3, 6, 8, 13, 14, 16, 20 maddelerini, kişisel başarı boyutu 4, 7, 9, 12, 17, 18, 19, 21 maddelerini ve, duyarsızlaşma boyutunu 5, 10, 11, 15, 22 maddelerini içermektedir. Duygusal tükenme ve duyarsızlasma alt boyutları olumsuz, kişisel basarı alt boyutu ise olumlu ifadeler içermektedir. Olumlu ifadeler ters yönde puanlanmıştır. Duygusal tükenme ve duyarsızlaşma boyutlarından alınan yüksek puan ile kişisel başarı boyutundan alınan düşük puan yüksek derece tükenmişliği göstermektedir.

Bu çalışmada kullanılan "Maslach Tükenmişlik Ölçeği'nin" araştırmadaki güvenirlik değerlerini belirlemek amacıyla iç tutarlık analizi yapılmıştır. Ölçeğinin cronbach alfa sayısı 0.88 olarak bulunmuştur. Alt ölçeklerde cronbach alfa duygusal tükenme için 0.878 , duyarsızlaşma için 0.71 , kişisel başarı için 0.70 'tür. Ölçeğin geçerlilik ve güvenilirlik çalışması sırasında elde edilen Cronbach Alfa katsayıları ise duygusal tükenme için 0.83 , duyarsızlaşma için 0.72 ve kişisel başarı hissinde azalma için 0.67 'dir (Ergin, 1992).

\section{Verilerin Çözümlenmesi}

Araştırma verilerinin analizinde SPSS 21 programından yararlanılmıştır. Tablo 1 'de bağımlı değişkenlere ait betimleyici istatistikler yer almaktadır. Bağımlı değişkenlere ait en düşük ortalama 1.75 ile duyarsızlaşma alt boyutuna, en yüksek ortalama ise 3.66 ile içsel doyum alt boyutuna aittir. Bağımlı değişkenlerin normallik varsayımını karşılayıp karşılamadığını öğrenmek için basıklık ve çarpıklık katsayılarına bakılmıştır. Basıklık katsayısı -.58 ile .53 aralığında; çarpıklık katsayısı ise - .55 ile .85 aralığında yer almaktadır. Bu değerler normallik varsayımının karşılandığını belirtmektedir. Çarpıklık ve basıklık değerlerinin -1 ile +1 arasında bir değer alması da verilerin normal dağıldığını göstermektedir. (Can, 2016:110).

Bu nedenle verilerin analizinde parametrik testlerden yararlanılmıştır. Aynı zamanda her bir analizde varyansların homojenliği varsayımı test edilmiş ve her bir analiz için levene testi değerinin. 05’ten yüksek olduğu görülmüştür. Araştırma kapsamında ikili bağımsız örneklemler için $t$ testi ve tek yönlü varyans analizi (ANOVA) kullanılmış, ölçek puanları arasındaki ilişkinin saptanmasında Pearson korelasyon analizi uygulanmıştır. İki grup arasındaki farklılıkların inelenmesi için bağımsız 
örneklemler için $t$ testi kullanılmıştır. Bağımsız örneklemler için $t$ testi çıktısının yorumlanmasında iki kademeli bir işlem söz konusudur. Birinci kademede Levene testi yardımıyla varyansların eşit olup olmadığına bakılır. İkinci kademede ise birinci kademe sonucuna göre "equal variance assumed (varyansların eşit olması durumu)" veya "equal variance not assumed (varyansların farklı olma durumu)" satırlarındaki t değerine ait "Significance (2-tailed)" değerine bakılarak yorum yapılmaktadır. SPSS programında anlamlılık düzeyi olarak Default (normal olarak verilen değer veya başlangıç değeri) değeri olarak $\% 5$ anlamlılık düzeyi kullanılmaktadır. T-testi sonuçlarının yorumlanmasında ise hesaplanan $t$ değerine karşılık gelen anlamlılık seviyesi olan "Significance (2-tailed)" değerinin \%5 anlamlılık düzeyi için 0.05 ’ten (veya \%1 anlamlılık seviyesi için ise 0.01'den) küçük olması halinde karşılaştırılan iki grup arasında incelenen özellik açısından anlamlı fark vardır yorumu yapılır (Altunışık ve diğ., 2012: 190). Araştırmada ikiden fazla grubun karşılaştırmasında ise tek yönlü varyans analizi (ANOVA) uygulanmış, farkın hangi gruptan kaynaklandığının tespiti için ise varyansların homojen dağılması nedeniyle Post-hoc TUKEY testi kullanılmıştır.

Tablo 1. Bağımlı değişkenlere ait betimleyici istatistikler

\begin{tabular}{lccccc}
\hline & $\mathbf{n}$ & Ort & Ss & Çarpıklık & Basıklık \\
\hline Duygusal tükenmişlik & 152 & 2.42 & .77 & .21 & -.58 \\
Düşük kişisel başarı & 152 & 2.32 & .50 & .24 & .53 \\
Duyarsızlaşma & 152 & 1.75 & .64 & .85 & -.10 \\
İçsel doyum & 152 & 3.66 & .59 & -.55 & .03 \\
Dışsal doyum & 152 & 3.05 & .73 & -.14 & -.23 \\
\hline
\end{tabular}

\section{BULGULAR}

\section{MTÖ ve MiDÖ Alt Boyutlarından Aldıkları Puanlara İlişkin Bulgular}

Bu bölümde katılımcıların Maslach Ölçeği ve Minnesota İş Doyum Ölçeğinin alt boyutlarından aldıkları en düşük ve en yüksek puanlar ile ortalama puanlar tablolar halinde gösterilmiştir.

Tablo 2. Katılımcıların Maslach Tükenmişlik Ölçeğinden aldıkları ortalama puanlar

\begin{tabular}{lccc}
\hline & N & Min - Max & Ort \pm Ss \\
\hline Duygusal Tükenmişlik & 152 & $1.00-4.44$ & $2.43 \pm .78$
\end{tabular}


Tablo 2'de katılımcıların Maslach Tükenmişlik Ölçeğinden aldıkları ortalama puanlar yer almaktadır. Katıımcıların alt boyutlara göre aldıkları ortalama puanlar, duygusal tükenmişlik alt boyutu için $2.43 \pm .78$, düşük kişisel başarı alt boyutu için $2.33 \pm .51$ ve duyarsızlaşma alt boyutu için $1.75 \pm .64$ 'tür. Buna göre duygusal tükenmişlik boyutu orta düzeydeyken, duyarsızlaşma ve düşük kişisel başarı boyutları düşük düzeydedir.

Tablo 3. Katılımcıların Minessota iş doyum ölçeğinden aldıkları ortalama puanlar

\begin{tabular}{lccc}
\hline & $\mathbf{N}$ & Min - Max & Ort \pm Ss \\
\hline İçsel Doyum & 152 & $2.00-4.92$ & $3.66 \pm .59$ \\
Dışsal Doyum & 152 & $1.13-4.88$ & $3.05 \pm .73$ \\
\hline
\end{tabular}

Tablo 3'de katılımcıların Minessota İş Doyum Ölçeğinden aldıkları ortalama puanlar yer almaktadır. Katılımcıların aldıkları ortalama puanlar, içsel doyum alt boyutu için $3.66 \pm .59$ ve dişsal doyum alt boyutu için $3.05 \pm .73$ 'tür. Buna göre içsel ve dışsal doyum düzeyi yüksektir.

\section{Korelasyon Analizine İlişkin Bulgular}

Tükenmişlik alt boyutları ve iş doyum alt boyutlarının birbiri ile olan ilişki derecesi ve yönüne bakmak amacıyla korelasyon analizi yapılmış ve aşağıda korelasyon analizinin sonuçları tablolarla gösterilmiştir.

Tablo 4. İş doyum düzeylerinin alt boyutları ile tükenmişlik düzeylerinin alt boyutlarının korelasyon sonuçları

\begin{tabular}{|c|c|c|c|c|c|}
\hline & $\begin{array}{c}\text { İçsel } \\
\text { Doyum }\end{array}$ & $\begin{array}{l}\text { Dişsal } \\
\text { Doyum }\end{array}$ & $\begin{array}{l}\text { Duygusal } \\
\text { Tükenme }\end{array}$ & $\begin{array}{l}\text { Düşük } \\
\text { Kişisel } \\
\text { Başarı }\end{array}$ & Duyarsızlaşma \\
\hline İçsel Doyum & 1 & , $690^{* *}$ &,$- 511^{* *}$ &,$- 552^{\star \star}$ &,$- 371^{\star \star}$ \\
\hline Dışsal Doyum &, $690^{* *}$ & 1 &,$- 470^{* *}$ &,$- 338^{* *}$ &,$- 263^{* *}$ \\
\hline $\begin{array}{l}\text { Duygusal } \\
\text { Tükenme }\end{array}$ &,$- 511^{\star *}$ &,$- 470^{\star *}$ & 1 &, $498^{\star *}$ &, $531^{\star *}$ \\
\hline $\begin{array}{l}\text { Düşük Kişisel } \\
\text { Başarı }\end{array}$ &,$- 552^{\star *}$ &,$- 338^{\star *}$ & , $498^{* *}$ & 1 &, $412^{* *}$ \\
\hline Duyarsızlaşma &,$- 371^{* *}$ &,$- 263^{* *}$ & $531^{* *}$ & $412^{* *}$ & 1 \\
\hline
\end{tabular}

${ }^{* *}$ Korelasyon 0.01 önem düzeyinde anlamlıdır. (Çift Kuyruklu)

Katılımcıların iş doyum düzeylerinin alt boyutları ile tükenmişlik düzeylerinin alt boyutlarının korelasyon sonuçlarını gösteren Tablo 4 incelendiğinde; katııımcıların içsel doyum düzeyleri ile dışsal doyum düzeyleri arasında pozitif $(r=0.690, p<.01)$, 
duygusal tükenme düzeyleri ( $r=-0.511, p<.01)$, duyarsızlaşma düzeyleri ( $r=-0.371$, $p<.01)$, düşük kişisel başarı düzeyleri $(r=-0.552, p<.01)$ arasında ise anlamlı, negatif yönde ilişki tespit edilmiştir.

Katılımcıların dışsal doyum düzeyleri ile duygusal tükenme düzeyleri ( $r=-0.470$, $p<.01)$, duyarsızlaşma düzeyleri $(r=-0.263, p<.01)$, düşük kişisel başarı düzeyleri $(r=-$ $0.338, p<.01$ ) arasında negatif ve anlamlı bir ilişki olduğu görülmektedir.

Katılımcıların duygusal tükenme düzeyleri ile duyarsızlaşma düzeyleri ( $r=0.531$, $p<.01)$, kişisel başarısızlık düzeyleri $(r=0.498, p<.01)$ arasında anlamlı, pozitif yönde ilişki tespit edilmiştir. Katılımcıların duyarsızlaşma düzeyleri ile kişisel başarısızlık düzeyleri arasında pozitif yönde ilişki bulunmuştur $(r=0.412, p<.01)$.

\section{Katılımcıların MTÖ ve MIDÖ Alt Boyutlarından Aldıkları Puanların, Sosyo- Demografik Özelliklerine Göre Anlamlı Bir Farklılık Gösterip Göstermediğine İlişkin Bulgular}

Katılımcıların tükenmişlik düzeyi alt boyutları ile iş doyumu alt boyutlarının katılımcıların sosyo-ekonomik ve demografik özelliklerine göre anlamlı bir farklılık gösterip göstermediğini bulmak amacıyla Bağımsız Örneklem T-Testi ve Tek Faktörlü Varyans Analizi yapılmıştır.

Tablo 5'de katılımcıların tükenmişlik düzeyi ve iş doyumu alt boyutlarının yaş değişkenine ilişkin bağımsız örneklem t testi yer almaktadır.

Tablo 5. Katılımcıların Yaşlarına Göre Analiz Sonuçları

\begin{tabular}{llcccccc}
\hline & Yaş & $\mathrm{n}$ & Ort & $\mathrm{Ss}$ & $\mathrm{sd}$ & $\mathrm{t}$ & $\mathrm{p}$ \\
\hline Duygusal & Genç & 121 & 2.44 & .77 & 150 & .688 & .49 \\
\hline Tükenmişlik & Yetişkinlik & 121 & & & \\
\hline
\end{tabular}




\begin{tabular}{|c|c|c|c|c|c|c|c|}
\hline & $\begin{array}{l}\text { Orta } \\
\text { Yetişkinlik }\end{array}$ & 31 & 2.34 & .81 & & & \\
\hline \multirow{2}{*}{$\begin{array}{l}\text { Düşük } \\
\text { Kişilerarası } \\
\text { Başarı }\end{array}$} & $\begin{array}{l}\text { Genç } \\
\text { Yetişkinlik }\end{array}$ & 121 & 2.34 & .48 & \multirow{2}{*}{150} & \multirow{2}{*}{.634} & \multirow{2}{*}{.53} \\
\hline & $\begin{array}{l}\text { Orta } \\
\text { Yetişkinlik }\end{array}$ & 31 & 2.27 & .58 & & & \\
\hline \multirow{2}{*}{ Duyarsızlaşma } & $\begin{array}{l}\text { Genç } \\
\text { Yetişkinlik }\end{array}$ & 121 & 1.77 & .63 & \multirow{2}{*}{150} & \multirow{2}{*}{1.084} & \multirow{2}{*}{.28} \\
\hline & $\begin{array}{l}\text { Orta } \\
\text { Yetişkinlik }\end{array}$ & 31 & 1.63 & .66 & & & \\
\hline \multirow[b]{2}{*}{ İçsel Doyum } & $\begin{array}{l}\text { Genç } \\
\text { Yetişkinlik }\end{array}$ & 121 & 3.65 & .59 & \multirow{2}{*}{150} & \multirow{2}{*}{-.511} & \multirow[b]{2}{*}{.61} \\
\hline & $\begin{array}{l}\text { Orta } \\
\text { Yetişkinlik }\end{array}$ & 31 & 3.71 & .57 & & & \\
\hline \multirow{2}{*}{ Dışsal Doyum } & $\begin{array}{l}\text { Genç } \\
\text { Yetişkinlik }\end{array}$ & 121 & 3.02 & .72 & \multirow{2}{*}{150} & \multirow{2}{*}{-.802} & \multirow{2}{*}{.42} \\
\hline & $\begin{array}{l}\text { Orta } \\
\text { Yetişkinlik }\end{array}$ & 31 & 3.14 & .74 & & & \\
\hline
\end{tabular}

Tablo 5'de katılımcıların tükenmişlik düzeyi ve iş doyumu alt boyutlarının yaş gruplarına göre bağımsız örneklem $t$ testi yer almaktadır. Yapılan analiz sonucunda duygusal tükenmişlik ( $\mathrm{t}=.688, \mathrm{p}>.05)$, düşük kişisel başarı $(\mathrm{t}=.634$, $p>.05)$, duyarsızlaşma ( $t=1.084, p>.05)$, içsel doyum ( $t=-.511, p>.05)$ ve dışsal doyum ( $t=-.802, p>.05)$ boyutlarında anlamlı farklılık bulunmamaktadır.

Tablo 6'da katılımcıların tükenmişlik düzeyi ve iş doyumu alt boyutlarının çalışılan kuruma ilişkin ANOVA sonuçları yer almaktadır. 
Tablo 6. Katıımcıların çalıştıkları kuruma göre ANOVA sonuçları

\begin{tabular}{|c|c|c|c|c|c|c|c|}
\hline Ölçek & Kurum & $\mathbf{n}$ & Ort & Ss & $\mathbf{F}$ & $\mathbf{P}$ & Fark \\
\hline \multirow{5}{*}{$\begin{array}{l}\text { Duygusal } \\
\text { Tükenmişlik }\end{array}$} & a.ASPB & 90 & 2.36 & .77 & \multirow{5}{*}{1.195} & \multirow{5}{*}{.32} & \\
\hline & $\begin{array}{l}\text { b.Adalet } \\
\text { Bakanlığı }\end{array}$ & 20 & 2.77 & .71 & & & \\
\hline & c.Belediye & 17 & 2.37 & .80 & & & \\
\hline & d.KYK & 2 & 2.27 & 1.02 & & & \\
\hline & $\begin{array}{l}\text { e.Sağlık } \\
\text { Bakanlığı }\end{array}$ & 21 & 2.37 & .80 & & & \\
\hline \multirow[b]{2}{*}{ Düşük } & a.ASPB & 90 & 2.28 & .52 & \multirow{5}{*}{2.360} & \multirow{5}{*}{.06} & \\
\hline & $\begin{array}{l}\text { b.Adalet } \\
\text { Bakanlığı }\end{array}$ & 20 & 2.63 & .49 & & & \\
\hline Kişisel & c.Belediye & 17 & 2.19 & .54 & & & \\
\hline \multirow[b]{2}{*}{ Başarı } & d.KYK & 2 & 2.31 & .08 & & & \\
\hline & $\begin{array}{l}\text { e.Sağlık } \\
\text { Bakanlığı }\end{array}$ & 21 & 2.32 & .32 & & & \\
\hline \multirow{5}{*}{ Duyarsızlaşma } & a.ASPB & 90 & 1.76 & .60 & \multirow{5}{*}{.945} & \multirow{5}{*}{.44} & \\
\hline & $\begin{array}{l}\text { b.Adalet } \\
\text { Bakanlığı }\end{array}$ & 20 & 1.81 & .60 & & & \\
\hline & c.Belediye & 17 & 1.85 & .80 & & & \\
\hline & d.KYK & 2 & 1.30 & .14 & & & \\
\hline & $\begin{array}{l}\text { e.Sağlık } \\
\text { Bakanlığı }\end{array}$ & 21 & 1.55 & .60 & & & \\
\hline \multirow{3}{*}{ İçsel } & a.ASPB & 90 & 3.65 & .61 & \multirow{5}{*}{3.642} & \multirow{5}{*}{.01} & \multirow{3}{*}{$c>b$} \\
\hline & $\begin{array}{l}\text { b.Adalet } \\
\text { Bakanlığı }\end{array}$ & 20 & 3.28 & .49 & & & \\
\hline & c.Belediye & 17 & 3.94 & .37 & & & \\
\hline \multirow[t]{3}{*}{ Doyum } & d.KYK & 2 & 3.79 & .41 & & & \multirow[t]{2}{*}{$e>b$} \\
\hline & $\begin{array}{l}\text { e.Sağlık } \\
\text { Bakanlığı }\end{array}$ & 21 & 3.82 & .59 & & & \\
\hline & a.ASPB & 90 & 3.05 & .74 & \multirow{5}{*}{4.173} & \multirow{5}{*}{.00} & \multirow{3}{*}{$c>b$} \\
\hline \multirow[t]{2}{*}{ Dışsal } & $\begin{array}{l}\text { b.Adalet } \\
\text { Bakanlığı }\end{array}$ & 20 & 2.56 & .69 & & & \\
\hline & c.Belediye & 17 & 3.50 & .72 & & & \\
\hline \multirow[t]{2}{*}{ Doyum } & d.KYK & 2 & 2.87 & .35 & & & \multirow[t]{2}{*}{$e>b$} \\
\hline & $\begin{array}{l}\text { e.Sağlık } \\
\text { Bakanlığı }\end{array}$ & 21 & 3.14 & .48 & & & \\
\hline
\end{tabular}

Tablo 6'da yer alan ANOVA sonucunda, çalışılan kuruma göre, duygusal tükenmişlik, düşük kişiler arası başarı, duyarsızlaşma alt boyutlarında anlamlı farklılık bulunmazken ( $p>.05)$ içsel doyum $(F=3.642, p<.05)$ ve dişsal doyum $(\mathrm{F}=4.173, \mathrm{p}<.05)$ alt boyutlarında anlamlı farklılık bulunmuştur. Uygulanan Tukey testi sonucunda içsel doyum ve dışsal doyum alt boyutlarında, belediye ve Sağlık Bakanlığı çalışanlarının puanı Adalet Bakanlığı çalışanlarından daha yüksek bulunmuştur.

Tablo 7'de katılımcıların tükenmişlik düzeyi ve iş doyumu alt boyutlarının haftalık toplam çalışma saatine ilişkin ANOVA sonuçları yer almaktadır. 
Tablo 7. Katılımcıların haftalık toplam çalışma saatine göre ANOVA sonuçları

\begin{tabular}{|c|c|c|c|c|c|c|c|}
\hline Ölçek & Çalışma Saati & $\mathbf{n}$ & Ort & Ss & $\mathbf{F}$ & $\mathbf{P}$ & Fark \\
\hline \multirow{3}{*}{$\begin{array}{l}\text { Duygusal } \\
\text { Tükenmişlik }\end{array}$} & a. $20-30$ & 11 & 2.11 & .85 & \multirow{3}{*}{2.246} & \multirow{3}{*}{.11} & \\
\hline & b. $30-40$ & 99 & 2.38 & .72 & & & \\
\hline & c.40 ve üzeri & 42 & 2.61 & .85 & & & \\
\hline \multirow{3}{*}{$\begin{array}{l}\text { Düşük } \\
\text { Kişisel } \\
\text { Başarı }\end{array}$} & a. $20-30$ & 11 & 2.59 & .76 & \multirow{3}{*}{2.106} & \multirow{3}{*}{.12} & \\
\hline & b. $30-40$ & 99 & 2.33 & .45 & & & \\
\hline & c.40 ve üzeri & 42 & 2.24 & .53 & & & \\
\hline \multirow{3}{*}{ Duyarsızlaşma } & a. $20-30$ & 11 & 1.76 & .64 & \multirow{3}{*}{.015} & \multirow{3}{*}{.98} & \\
\hline & b. $30-40$ & 99 & 1.74 & .60 & & & \\
\hline & c.40 ve üzeri & 42 & 1.76 & .73 & & & \\
\hline \multirow{3}{*}{$\begin{array}{l}\text { İçsel } \\
\text { Doyum }\end{array}$} & a. $20-30$ & 11 & 3.85 & .69 & \multirow{3}{*}{1.226} & \multirow{3}{*}{.29} & \\
\hline & b. $30-40$ & 99 & 3.61 & .56 & & & \\
\hline & c.40 ve üzeri & 42 & 3.73 & .63 & & & \\
\hline \multirow{3}{*}{$\begin{array}{l}\text { Dışsal } \\
\text { Doyum }\end{array}$} & a. $20-30$ & 11 & 3.50 & .77 & \multirow{3}{*}{3.052} & \multirow{3}{*}{.05} & \multirow{3}{*}{$a>b$} \\
\hline & b. $30-40$ & 99 & 2.96 & .65 & & & \\
\hline & c.40 ve üzeri & 42 & 3.13 & .84 & & & \\
\hline
\end{tabular}

Tablo 7'de yer alan ANOVA sonucunda, haftalık toplam çalışma saati değişkenine göre, duygusal tükenmişlik, düşük kişisel başarı, duyarsızlaşma ve içsel doyum alt boyutlarında anlamlı farklılık bulunmazken ( $p>.05)$ dışsal doyum alt boyutunda anlamlı farklılık bulunmuştur $(F=3.052, p=.05)$. Tukey testi sonucunda haftalık çalışma saati "20-30 saat" aralığında olan bireylerin "30-40 saat" aralığında olan bireylere göre dışsal doyum düzeyleri daha yüksek bulunmuştur.

Tablo 8'de katılımcıların tükenmişlik düzeyi ve iş doyumu alt boyutlarının kıdem durumuna ilişkin ANOVA sonuçları yer almaktadır. 
Tablo 8. Katılımcıların kıdeme göre ANOVA sonuçları

\begin{tabular}{|c|c|c|c|c|c|c|c|}
\hline Ölçek & Kıdem & $\mathbf{N}$ & Ort & Ss & $\mathbf{F}$ & $\mathbf{P}$ & Fark \\
\hline \multirow{4}{*}{$\begin{array}{l}\text { Duygusal } \\
\text { Tükenmişlik }\end{array}$} & a.0-1 yıl & 20 & 2.17 & .66 & \multirow{4}{*}{1.576} & \multirow{4}{*}{.19} & \\
\hline & b. $2-5$ & 60 & 2.44 & .76 & & & \\
\hline & c.5-10 yıl & 15 & 2.74 & .63 & & & \\
\hline & d.10 ve üzeri & 57 & 2.42 & .86 & & & \\
\hline \multirow{2}{*}{ Düşük } & a. 0-1 yıl & 20 & 2.27 & .34 & \multirow{4}{*}{.348} & \multirow{4}{*}{.79} & \\
\hline & b.2-5 & 60 & 2.33 & .55 & & & \\
\hline \multirow{2}{*}{ Başarı } & c.5-10 yıl & 15 & 2.44 & .53 & & & \\
\hline & d.10 ve üzeri & 57 & 2.32 & .51 & & & \\
\hline \multirow{4}{*}{ Duyarsızlaşma } & a. $0-1$ yıl & 20 & 1.78 & .55 & \multirow{4}{*}{.639} & \multirow{4}{*}{.59} & \\
\hline & b.2-5 & 60 & 1.80 & .59 & & & \\
\hline & c.5-10 yıl & 15 & 1.85 & .78 & & & \\
\hline & d.10 ve üzeri & 57 & 1.66 & .69 & & & \\
\hline \multirow{4}{*}{$\begin{array}{l}\text { İçsel } \\
\text { Doyum }\end{array}$} & a.0-1 yıl & 20 & 3.69 & .55 & \multirow{4}{*}{3.199} & \multirow{4}{*}{.02} & \\
\hline & b.2-5 & 60 & 3.68 & .59 & & & \\
\hline & c.5-10 yıl & 15 & 3.23 & .62 & & & \\
\hline & d.10 ve üzeri & 57 & 3.75 & .57 & & & \\
\hline \multirow{4}{*}{$\begin{array}{l}\text { Dışsal } \\
\text { Doyum }\end{array}$} & a.0-1 yıl & 20 & 3.20 & .67 & \multirow{4}{*}{2.319} & \multirow{4}{*}{.08} & $a>c$ \\
\hline & b. $2-5$ & 60 & 3.09 & .76 & & & $b>c$ \\
\hline & c.5-10 yıl & 15 & 2.60 & .64 & & & \\
\hline & d.10 ve üzeri & 57 & 3.07 & .71 & & & $d>c$ \\
\hline
\end{tabular}

Tablo 8'de yer alan ANOVA sonucunda, kıdem değişkenine göre, duygusal tükenmişlik, düşük kişilsel başarı, duyarsızlaşma ve dışsal doyum alt boyutlarında anlamlı farklılık bulunmazken ( $p>05$ ) içsel doyum alt boyutunda anlamlı farklılık bulunmuştur $(F=3.199, p<.05)$. Tukey testi sonucunda, kıdemi "5-10 yıl" ( $x=3.23)$ aralığında olan bireylerin içsel doyum düzeyleri, kıdem yılı "0-1" ( $x=3.69)$, "2-5" $(x=3.68)$ ve "10 üzeri" ( $x=3.75)$ olan bireylere göre daha düşük bulunmuştur. 
Tablo 9. Katılımcıların Meslek Seçim Durumuna Göre Analiz Sonuçları

\begin{tabular}{|c|c|c|c|c|c|c|c|}
\hline Ölçek & Meslek Seçimi & $\mathbf{N}$ & Ort & $\mathbf{S}$ & sd & $t$ & $\mathbf{P}$ \\
\hline \multirow{2}{*}{ Duygusal Tükenmişlik } & İsteyerek & 123 & 2.28 & .73 & \multirow{2}{*}{150} & \multirow{2}{*}{-5.223} & \multirow{2}{*}{.00} \\
\hline & İstemeyerek & 28 & 3.07 & .68 & & & \\
\hline \multirow{2}{*}{ Düşük Kişisel Başarı } & İsteyerek & 123 & 2.24 & .48 & \multirow{2}{*}{150} & \multirow{2}{*}{-4.802} & \multirow[b]{2}{*}{.00} \\
\hline & İstemeyerek & 28 & 2.72 & .44 & & & \\
\hline \multirow{2}{*}{ Duyarsızlaşma } & İsteyerek & 123 & 1.65 & .61 & \multirow{2}{*}{150} & \multirow[b]{2}{*}{-4.344} & \multirow[b]{2}{*}{.00} \\
\hline & İstemeyerek & 28 & 2.20 & .61 & & & \\
\hline \multirow{2}{*}{ İçsel Doyum } & İsteyerek & 123 & 3.74 & .57 & \multirow{2}{*}{150} & \multirow{2}{*}{3.833} & \multirow{2}{*}{.00} \\
\hline & İstemeyerek & 28 & 3.29 & .56 & & & \\
\hline \multirow{2}{*}{ Dışsal Doyum } & İsteyerek & 123 & 3.11 & .72 & \multirow{2}{*}{150} & \multirow{2}{*}{2.245} & \multirow{2}{*}{.00} \\
\hline & İstemeyerek & 28 & 2.77 & .73 & & & \\
\hline
\end{tabular}

Tablo 9'da katılımcıların tükenmişlik düzeyi ve iş doyumu alt boyutlarının meslek seçim değişkenine ilişkin bağımsız örneklem t testi yer almaktadır. Yapılan analiz sonucunda duygusal tükenmişlik ( $t=-5.223, p<.05)$, düşük kişisel başarı ( $t=-4.802$, $p<.05)$, duyarsızlaşma $(t=-4.344, p<.05)$, içsel doyum $(t=3.833, p<.05)$ ve dışsal doyum ( $\mathrm{t}=2.245, \mathrm{p}<.05)$ boyutlarında farklılık anlamlı bulunmuştur. Mesleğini isteyerek seçen bireylerin içsel ve dışsal doyum puanları daha yüksek çıkarken; mesleğini istemeyerek seçen bireylerin duygusal tükenmişlik, düşük kişisel başarı ve duyarsızlaşma puanları daha yüksek bulunmuştur.

Tablo 10 'da katıımcıların tükenmişlik düzeyi ve iş doyumu alt boyutlarının mesleki yeterliğe ilişkin ANOVA sonuçları yer almaktadır.

Tablo 10. Katılımcıların mesleki yeterliğine göre ANOVA sonuçları

\begin{tabular}{|c|c|c|c|c|c|c|c|}
\hline Ölçek & Mesleki Yeterlilik & $\mathbf{n}$ & Ort & Ss & $\mathbf{F}$ & $\mathbf{P}$ & Fark \\
\hline \multirow{3}{*}{$\begin{array}{l}\text { Duygusal } \\
\text { Tükenmişlik }\end{array}$} & a.Yeterli & 79 & 2.25 & .77 & \multirow{3}{*}{4.257} & \multirow{3}{*}{.02} & \\
\hline & b.Yeterli değil & 17 & 2.58 & .64 & & & $b>a$ \\
\hline & c.Kısmen yeterli & 56 & 2.62 & .77 & & & $\mathrm{c}>\mathrm{a}$ \\
\hline \multirow{3}{*}{$\begin{array}{l}\text { Düşük } \\
\text { Kişisel } \\
\text { Başarı }\end{array}$} & a.Yeterli & 79 & 2.23 & .50 & \multirow{3}{*}{4.218} & \multirow{3}{*}{.02} & \\
\hline & b.Yeterli değil & 17 & 2.58 & .54 & & & $b>a$ \\
\hline & c.Kısmen yeterli & 56 & 2.38 & .47 & & & $\mathrm{c}>\mathrm{a}$ \\
\hline \multirow[t]{3}{*}{ Duyarsızlaşma } & a.Yeterli & 79 & 1.70 & .66 & \multirow{3}{*}{.736} & \multirow{3}{*}{.48} & \\
\hline & b.Yeterli değil & 17 & 1.68 & .41 & & & \\
\hline & c.Kısmen yeterli & 56 & 1.83 & .65 & & & \\
\hline \multirow{3}{*}{$\begin{array}{l}\text { İçsel } \\
\text { Doyum }\end{array}$} & a.Yeterli & 79 & 3.91 & .42 & \multirow{3}{*}{18.522} & \multirow{3}{*}{.00} & \\
\hline & b.Yeterli değil & 17 & 3.29 & .68 & & & $a>b$ \\
\hline & c.Kısmen yeterli & 56 & 3.41 & .61 & & & $a>b$ \\
\hline \multirow{3}{*}{$\begin{array}{l}\text { Dişsal } \\
\text { Doyum }\end{array}$} & a.Yeterli & 79 & 3.21 & .66 & \multirow{3}{*}{4.334} & \multirow{3}{*}{.02} & \\
\hline & b.Yeterli değil & 17 & 2.78 & .80 & & & $a>b$ \\
\hline & c.Kısmen yeterli & 56 & 2.90 & .75 & & & $a>b$ \\
\hline
\end{tabular}


Tablo 10'da yer alan ANOVA sonucunda, mesleki yeterlik değişkenine göre, duyarsızlaşma alt boyutunda anlamlı farklılık görülmezken ( $p>05)$, duygusal tükenmişlik $(F=4.257, p<.05)$, düşük kişiler arası başarı $(F=4.218, p<.05)$, içsel doyum $(F=18.522, p<.05)$ ve dışsal doyum $(F=4.334, p<.05)$ alt boyutlarında anlamlı farklılık bulunmuştur. Tukey testi sonucunda, duygusal tükenmişlik, düşük kişisel başarı alt boyutunda, mesleki yeterliliğini "kısmen yeterli" ve "yeterli değil" olarak belirten bireylerin puanı, "yeterli" olan bireylere göre daha yüksekken; içsel doyum ve dışsal doyum alt boyutlarında kendini mesleki anlamda yeterli gören çalışanların puanı, kendini "yeterli değil" ve "kısmen yeterli" gören çalışanlara göre daha yüksek bulunmuştur.

Tablo 11'de katılımcıların tükenmişlik düzeyi ve iş doyumu alt boyutlarının verdikleri hizmeti değerlendirmesine ilişkin ANOVA sonuçları yer almaktadır.

Tablo 11. Katılımcıların verdikleri hizmeti değerlendirmelerine göre ANOVA sonuçları

\begin{tabular}{|c|c|c|c|c|c|c|c|}
\hline Ölçek & Verilen Hizmet & $\mathbf{n}$ & Ort & Ss & $\mathbf{F}$ & $\mathbf{P}$ & Fark \\
\hline Duygusal & a.Yeterli & 75 & 2.19 & .75 & \multirow{3}{*}{6.835} & \multirow{3}{*}{.00} & \multirow{3}{*}{$b>a$} \\
\hline \multirow[t]{2}{*}{ Tükenmişlik } & b.Yeterli değil & 18 & 2.62 & .98 & & & \\
\hline & c.Kısmen yeterli & 59 & 2.65 & .66 & & & \\
\hline Düşük & a.Yeterli & 75 & 2.20 & .51 & \multirow{3}{*}{4.837} & \multirow{3}{*}{.01} & \\
\hline Kişisel & b.Yeterli değil & 18 & 2.53 & .55 & & & $b>a$ \\
\hline Başarı & c.Kısmen yeterli & 59 & 2.42 & .44 & & & $\mathrm{C}>\mathrm{a}$ \\
\hline \multirow[t]{3}{*}{ Duyarsızlaşma } & a.Yeterli & 75 & 1.66 & .63 & \multirow{3}{*}{1.382} & \multirow{3}{*}{.25} & \\
\hline & b.Yeterli değil & 18 & 1.74 & .62 & & & \\
\hline & c.Kısmen yeterli & 59 & 1.85 & .65 & & & \\
\hline İçsel & a.Yeterli & 75 & 3.94 & .44 & \multirow{3}{*}{22.192} & \multirow{3}{*}{.00} & \multirow{3}{*}{$\begin{array}{l}a>b \\
a>b\end{array}$} \\
\hline \multirow[t]{2}{*}{ Doyum } & b.Yeterli değil & 18 & 3.25 & .81 & & & \\
\hline & c.Kısmen yeterli & 59 & 3.42 & .50 & & & \\
\hline Dışsal & a.Yeterli & 75 & 3.31 & .63 & \multirow{3}{*}{12.409} & \multirow{3}{*}{.00} & \multirow{3}{*}{$\begin{array}{l}a>b \\
a>b\end{array}$} \\
\hline \multirow[t]{2}{*}{ Doyum } & b.Yeterli değil & 18 & 2.57 & .87 & & & \\
\hline & c.Kısmen yeterli & 59 & 2.85 & .67 & & & \\
\hline
\end{tabular}

Tablo 11'de yer alan ANOVA sonucunda, çalışanların verdikleri hizmeti değerlendirme değişkenine göre, duyarsızlaşma alt boyutunda anlamlı farklılık 
görülmezken ( $p>.05)$, duygusal tükenmişlik $(F=6.835, p<.05)$, düşük kişiler arası başarı $(F=4.837, p<.05)$, içsel doyum $(F=22.192, p<.05)$ ve dışsal doyum $(F=12.409$, $\mathrm{p}<.05$ ) alt boyutlarında anlamlı farklılık bulunmuştur. Tukey testi sonucunda, duygusal tükenmişlik, düşük kişisel başarı alt boyutunda, verdiği hizmeti "kısmen yeterli" ve "yeterli değil" olarak belirten bireylerin puanı, "yeterli" olan bireylere göre daha yüksekken; içsel doyum ve dışsal doyum alt boyutlarında verdiği hizmeti yeterli gören çalışanların puanı, verdiği hizmeti "yeterli değil" ve "kısmen yeterli" gören çalışanlara göre daha yüksek bulunmuştur.

Tablo 12'de katıımcıların tükenmişlik düzeyi ve iş doyumu alt boyutlarının yönetici ile iletişimlerine ilişkin ANOVA sonuçları bulunmaktadır.

Tablo 12. Katılımcıların yönetici ile iletişimlerine göre ANOVA sonuçları

\begin{tabular}{|c|c|c|c|c|c|c|c|}
\hline Ölçek & Yönetici ile iletişim & $\mathbf{N}$ & Ort & Ss & $\mathbf{F}$ & $\mathbf{P}$ & Fark \\
\hline \multirow{4}{*}{$\begin{array}{l}\text { Duygusal } \\
\text { Tükenmişlik }\end{array}$} & a.Çok iyi & 21 & 2.13 & .89 & \multirow{4}{*}{7.003} & \multirow{4}{*}{.00} & $c>a$ \\
\hline & b. İyi & 81 & 2.27 & .72 & & & $d>b$ \\
\hline & c.Orta & 40 & 2.82 & .67 & & & $c>b$ \\
\hline & d.Kötü & 9 & 2.82 & .67 & & & $d>a$ \\
\hline \multirow{4}{*}{$\begin{array}{l}\text { Düşük } \\
\text { Kişisel } \\
\text { Başarı }\end{array}$} & a.Çok iyi & 21 & 2.16 & .40 & \multirow{4}{*}{3.658} & \multirow{4}{*}{.01} & $d>a$ \\
\hline & b. Iyi & 81 & 2.27 & .51 & & & $c>b$ \\
\hline & c.Orta & 40 & 2.46 & .48 & & & \\
\hline & d.Kötü & 9 & 2.68 & .59 & & & \\
\hline \multirow[t]{4}{*}{ Duyarsızlaşma } & a.Çok iyi & 21 & 1.62 & .76 & \multirow{4}{*}{2.747} & \multirow{4}{*}{.04} & \\
\hline & b.İyi & 81 & 1.66 & .58 & & & \\
\hline & c.Orta & 40 & 1.92 & .63 & & & \\
\hline & d.Kötü & 9 & 2.11 & .67 & & & \\
\hline \multirow{4}{*}{$\begin{array}{l}\text { İçsel } \\
\text { Doyum }\end{array}$} & a.Çok iyi & 21 & 4.00 & .52 & \multirow{4}{*}{8.228} & \multirow{4}{*}{.00} & $a>d$ \\
\hline & b. İyi & 81 & 3.74 & .47 & & & $b>c$ \\
\hline & c.Orta & 40 & 3.40 & .61 & & & $a>c$ \\
\hline & d.Kötü & 9 & 3.21 & .88 & & & $b>d$ \\
\hline \multirow{4}{*}{$\begin{array}{l}\text { Dışsal } \\
\text { Doyum }\end{array}$} & a.Çok iyi & 21 & 3.43 & .68 & \multirow{4}{*}{12.648} & \multirow{4}{*}{.00} & $a>d$ \\
\hline & b. Iyi & 81 & 3.20 & .60 & & & $b>c$ \\
\hline & c.Orta & 40 & 2.63 & .64 & & & $a>c$ \\
\hline & d.Kötü & 9 & 2.40 & .86 & & & $b>d$ \\
\hline
\end{tabular}

Tablo 12'de yer alan ANOVA sonucunda, çalışanların yöneticileri ile ilişkilerine göre, duygusal tükenmişlik $(F=7.003, p<.05)$, düşük kişiler arası başarı $(F=3.658, p<.05)$, duyarsızlaşma $(F=2.747, p<.05)$, içsel doyum $(F=8.228, p<.05)$ ve dışsal doyum $(\mathrm{F}=12.648, \quad \mathrm{p}<.05)$ alt boyutlarında anlamlı farklılık bulunmuştur. Tukey testi sonucunda duygusal tükenmişlik ve düşük kişisel başarı boyutlarında, yönetici ile ilişkisi orta ve kötü olan bireylerin puanının, ilişkisi çok iyi ve iyi olan çalışanlara göre 
daha yüksek olduğu belirlenmiştir. Duyarsızlaşma alt boyutunda yöneticisi ile ilişkisi kötü olan çalışanların, ilişkisi iyi ve çok iyi olan çalışanlara göre daha yüksektir. İçsel doyum ve dışsal doyum boyutlarında yöneticisi ile ilişkisi çok iyi ve iyi olan çalışanların puanı, ilişkisi orta ve kötü olanlara göre daha yüksek olduğu bulunmuştur.

Tablo 13'de katılımcıların tükenmişlik düzeyi ve iş doyumu alt boyutlarının iş arkadaşları ile iletişimlerine ilişkin ANOVA sonuçları bulunmaktadır.

Tablo 13. Katılımcıların iş arkadaşları ile iletişim kalitesine göre ANOVA sonuçları

\begin{tabular}{|c|c|c|c|c|c|c|c|}
\hline Ölçek & $\begin{array}{c}\text { İş } \\
\text { arkadaşları } \\
\text { ile iletişim }\end{array}$ & $\mathbf{n}$ & Ort & Ss & $\mathbf{F}$ & $\mathbf{P}$ & Fark \\
\hline \multirow{3}{*}{$\begin{array}{l}\text { Duygusal } \\
\text { Tükenmişlik }\end{array}$} & a.Çok iyi & 46 & 2.21 & .77 & \multirow{3}{*}{4.106} & \multirow{3}{*}{.02} & \\
\hline & b. İyi & 90 & 2.45 & .79 & & & \\
\hline & c.Orta & 16 & 2.84 & .51 & & & $c>a$ \\
\hline \multirow{3}{*}{$\begin{array}{l}\text { Düşük } \\
\text { Kişisel } \\
\text { Başarı }\end{array}$} & a.Çok iyi & 46 & 2.24 & .47 & \multirow{3}{*}{2.207} & \multirow{3}{*}{.11} & \\
\hline & b.İyi & 90 & 2.33 & .51 & & & \\
\hline & c.Orta & 16 & 2.54 & .51 & & & \\
\hline \multirow[t]{3}{*}{ Duyarsızlaşma } & a.Çok iyi & 46 & 1.76 & .72 & \multirow{3}{*}{1.508} & \multirow{3}{*}{.23} & \\
\hline & b.İyi & 90 & 1.70 & .58 & & & \\
\hline & c. Orta & 16 & 2.00 & .65 & & & \\
\hline \multirow{3}{*}{$\begin{array}{l}\text { İçsel } \\
\text { Doyum }\end{array}$} & a.Çok iyi & 46 & 3.81 & .58 & \multirow{3}{*}{7.008} & \multirow{3}{*}{.00} & $a>c$ \\
\hline & b.İyi & 90 & 3.67 & .56 & & & \\
\hline & c.Orta & 16 & 3.19 & .55 & & & \\
\hline \multirow{3}{*}{$\begin{array}{l}\text { Dışsal } \\
\text { Doyum }\end{array}$} & a.Çok iyi & 46 & 3.13 & .74 & \multirow{3}{*}{3.796} & \multirow{3}{*}{.03} & $a>c$ \\
\hline & b.İyi & 90 & 3.09 & .72 & & & \\
\hline & c.Orta & 16 & 2.58 & .57 & & & \\
\hline
\end{tabular}

Tablo 13'de yer alan ANOVA sonucunda, çalışanların iş arkadaşları ile iletişim kalitesine göre, düşük kişisel başarı ve duyarsızlaşma alt boyutlarında anlamlı farklılık görülmezken ( $p>.05)$; duygusal tükenmişlik ( $F=4.106, p<.05)$, içsel doyum $(F=7.008, p<.05)$ ve dışsal doyum $(F=3.796, p<.05)$ alt boyutlarında anlamlı farklılık bulunmuştur. Tukey testi sonucunda, duygusal tükenmişlik alt boyutunda iş arkadaşı ile ilişki kalitesi orta olan çalışanların puanı, ilişki kalitesi çok iyi olanlara göre daha yüksek olduğu; içsel doyum ve dışsal doyum alt boyutlarında iş arkadaşları ile ilişki kalitesi çok iyi olan çalışanların puanı ilişki kalitesi orta olan çalışanlara göre daha yüksek olduğu bulunmuştur.

Tablo 14'de katılımcıların tükenmişlik düzeyi ve iş doyumu alt boyutlarının bağımsız karar verme süreçlerinin desteklenmesine ilişkin ANOVA sonuçları yer almaktadır. 
Tablo 14. Katılımcıların bağımsız karar verme sürecininin desteklenmesine göre ANOVA sonuçları

\begin{tabular}{|c|c|c|c|c|c|c|c|}
\hline Ölçek & $\begin{array}{l}\text { Bağımsız karar } \\
\text { verme sürecinin } \\
\text { desteklenmesi }\end{array}$ & $\mathbf{n}$ & Ort & Ss & $\mathbf{F}$ & $\mathbf{P}$ & Fark \\
\hline \multirow{3}{*}{$\begin{array}{l}\text { Duygusal } \\
\text { Tükenmişlik }\end{array}$} & a.Destekleniyor & 45 & 2.18 & .91 & \multirow{3}{*}{6.148} & \multirow{3}{*}{.00} & \multirow{3}{*}{$b>a$} \\
\hline & b.Desteklenmiyor & 31 & 2.79 & .62 & & & \\
\hline & $\begin{array}{l}\text { c.Kısmen } \\
\text { destekleniyor }\end{array}$ & 76 & 2.42 & .70 & & & \\
\hline \multirow{3}{*}{$\begin{array}{l}\text { Düşük } \\
\text { Kişisel } \\
\text { Başarı }\end{array}$} & a.Destekleniyor & 45 & 2.16 & .51 & \multirow{3}{*}{5.825} & \multirow{3}{*}{.00} & \multirow{3}{*}{$b>a$} \\
\hline & b.Desteklenmiyor & 31 & 2.56 & .60 & & & \\
\hline & $\begin{array}{l}\text { c.Kısmen } \\
\text { destekleniyor }\end{array}$ & 76 & 2.33 & .41 & & & \\
\hline \multirow[t]{3}{*}{ Duyarsızlaşma } & a.Destekleniyor & 45 & 1.55 & .56 & \multirow{3}{*}{5.802} & \multirow{3}{*}{.00} & \multirow{3}{*}{$b>a$} \\
\hline & b.Desteklenmiyor & 31 & 2.04 & .71 & & & \\
\hline & $\begin{array}{l}\text { c.Kısmen } \\
\text { destekleniyor }\end{array}$ & 76 & 1.74 & .61 & & & \\
\hline \multirow{3}{*}{$\begin{array}{l}\text { İçsel } \\
\text { Doyum }\end{array}$} & a.Destekleniyor & 45 & 3.94 & .44 & \multirow{3}{*}{18.435} & \multirow{3}{*}{.00} & $a>b$ \\
\hline & b.Desteklenmiyor & 31 & 3.18 & .62 & & & \\
\hline & $\begin{array}{l}\text { c.Kısmen } \\
\text { destekleniyor }\end{array}$ & 76 & 3.69 & .54 & & & \\
\hline \multirow{3}{*}{$\begin{array}{l}\text { Dışsal } \\
\text { Doyum }\end{array}$} & a.Destekleniyor & 45 & 3.41 & .70 & \multirow{3}{*}{12.129} & \multirow{3}{*}{.00} & \multirow[t]{3}{*}{$a>b$} \\
\hline & b.Desteklenmiyor & 31 & 2.64 & .66 & & & \\
\hline & $\begin{array}{l}\text { c.Kısmen } \\
\text { destekleniyor }\end{array}$ & 76 & 3.00 & .67 & & & \\
\hline
\end{tabular}

Tablo 14'de yer alan ANOVA sonucunda, bağımsız karar verme sürecinin desteklenmesi değişkenine göre, duygusal tükenmişlik $(F=6.148, p<.05)$, düşük kişisel başarı $(F=5.825, p<.05)$, duyarsızlaşma $(F=5.802, p<.05)$, içsel doyum $(\mathrm{F}=18.435, \mathrm{p}<.05)$ ve dışsal doyum $(\mathrm{F}=12.129, \mathrm{p}<.05)$ alt boyutlarında anlamlı farklılık bulunmuştur. Tukey testi sonucunda, duygusal tükenmişlik, düşük kişisel başarı ve duyarsızlaşma alt boyutlarında, bağımsız karar verme süreci desteklenmeyen çalışanların puanı, desteklenen çalışanlara göre daha yüksek bulunmuştur. İçsel doyum ve dışsal doyum alt boyutlarında bağımsız karar verme süreci desteklenen çalışanların puanı, desteklenmeyen çalışanlara göre daha yüksek bulunmuştur.

\section{TARTIŞMA}

Farklı sosyal hizmet kurumlarında çalışan sosyal hizmet uzmanlarının iş doyumu ve tükenmişlik düzeylerinin sosyo-demografik ve mesleki değişkenlere ilişkin bulguların tartışılması aşağıdaki gibidir. 
Katılımcıların tükenmişlik düzeyi ve iş doyumu alt boyutlarının yaş değişkenine göre duygusal tükenmişlik, düşük kişisel başarı, duyarsızlaşma, içsel ve dışsal doyum arasında anlamlı bir farklııı bulunmamıştır. Buna karşın İçağasıoğlu-Çoban ve Özbesler (2016) çalışmalarında sosyal hizmet uzmanlarının yaşları arttıkça duygusal tükenmenin arttığını, yaş azaldıkça duyarsızlaşma ve düşük kişisel başarının azaldığını tespit etmişlerdir. Işıkhan (2000) ise çalışmasında uzmanların yaşları arttıkça iş doyum düzeylerinin düştüğünü tespit etmiş bunun nedenin yükselme ve terfi olanaklarının kısıtııı̆ı olabileceğini belirtmiştir.

Katılımcıların tükenmişlik düzeyi ve iş doyumu alt boyutlarının kıdem durumuna göre duygusal tükenmişlik, düşük kişisel başarı, duyarsızlaşma, dışsal doyum arasında anlamlı bir farklılık bulunmamış, kıdem ile içsel doyum arasındaki fark anlamlı bulunmuştur. Yapılan analiz sonucunda, kıdemi "5-10 yıl" aralığında olan bireylerin içsel doyum düzeyleri, kıdem yılı "0-1", "2-5" ve "10 üzeri” olan bireylere göre daha düşük bulunmuştur. Uzun (2018) sosyal hizmet uzmanları ile yaptığı çalışmasında kıdem arttıkça tükenmişlik ve mobbinge maruz kalma düzeyinin azaldığını tespit etmiştir.

Katıımcıların tükenmişlik düzeyi ve iş doyumu alt boyutlarının katılımcıların kendilerini mesleki olarak yeterlilik değerlendirmelerine göre mesleki yeterlilik ile duyarsızlaşma düzeyi arasında anlamlı bir farklııı bulunmamış, duygusal tükenmişlik, düşük kişisel başarı, içsel ve dışsal doyum arasında anlamlı bir farklılık bulunmuştur. Sonuçlara göre bireyin kendini daha yetersiz hissettikçe tükenmişlik düzeyi, yeterli hissettikçe ise iş doyumu artmaktadır. Calitz ve diğ. (2014) sosyal hizmet uzmanlarının iş doyumu ve tükenmiş düzeyi üzerine yaptığı çalışmasında bireyin kendini yeterli hissettikçe tükenmişlik düzeyinin azaldığını belirtmiştir.

Katılımcıların tükenmişlik düzeyi ve iş doyumu alt boyutlarının katılımcıların verdikleri hizmeti değerlendirmelerine göre duyarsızlaşma düzeyi arasında anlamlı bir farklılık bulunmamış, duygusal tükenmişlik, düşük kişisel başarı, içsel ve dışsal doyum arasındaki fark istatistiksel anlamlı bulunmuştur. Sonuçlara göre katılımcıların değerlendirmeleri doğrultusunda müracaatçılar tarafından yetersiz olarak değerlendirildikçe tükenmişlik düzeyi, yeterli olarak değerlendirildikçe ise iş doyumu artmaktadır. Uğur ve Erol (2015) uzmanların, müracaatçılara fayda sağladıklarını hissetmezlerse benlik saygılarının zedelendiklerini ve stres düzeylerinin arttığını belirtmişlerdir. 
Katılımcıların tükenmişlik düzeyi ve iş doyumu alt boyutlarının katıımcıların yöneticileri ile olan iletişim kalitesini değerlendirmelerine göre duygusal tükenmişlik, düşük kişiler arası başarı, duyarsızlaşma, içsel doyum ve dışsal doyum alt boyutlarında anlamlı farklılıklar bulunmuştur. Sonuçlara göre katılımcıların yöneticileri ile iletişim kalitesi azaldıkça tükenmişlik düzeyi, yöneticileri ile iletişim kalitesi arttıkça ise iş doyumu artmaktadır. Martin (1988) sosyal hizmet uzmanları ile yaptığı araştırma sonucunda yöneticilerinden olumlu geribildirimler alan ve iletişim düzeyi yüksek olan uzmanların iş doyumlarının oldukça yüksek olduğunu saptamıştır. Ayrıca Yürür ve Sarıkaya (2011) sosyal hizmet uzmanlarının sahip olduğu yönetici desteğinin tükenmişlikle baş etmede etkili olduğunu belirtmişlerdir.

Katılımcıların tükenmişlik düzeyi ve iş doyumu alt boyutlarının katılımcıların iş arkadaşları ile olan iletişim kalitesini değerlendirmelerine göre düşük kişisel başarı ve duyarsızlaşma düzeyi arasında anlamlı bir farklııı bulunmamış, duygusal tükenmişlik, içsel ve dışsal doyum arasındaki fark anlamlı bulunmuştur. Sonuçlara göre katııımcıların iş arkadaşları ile iletişim kalitesi azaldıkça duygusal tükenmişlik düzeyi, iş arkadaşları ile iletişim kalitesi arttıkça ise iş doyumu artmaktadır. Yürür ve Sarıkaya (2011) çalışma arkadaşlarından gelen sosyal desteğin tükenmişliğin önlemesinde önemli bir etken olduğunu belirtmiştir. Benzer olarak Ceylan ve diğ. (2016) çalışma arkadaşlarının değerlendirmelerinin tükenmişlik ve iş doyumu ile bağlantılı olduğunu belirtmiştir. İçağasıoğlu-Çoban ve Özbesler (2016) ise çalışmalarında sosyal hizmet uzmanlarının iş arkadaşları ile kurdukları ilişkiden memnun olma durumunun kişisel başarıyı pozitif yönde etkilediğini tespit etmişler, arkadaşları ile ilişkilerinin çok iyi olduğunu söyleyen uzmanların kişisel alanda kendilerini daha başarılı hissettiklerini belirtmişlerdir.

Katıımcıların tükenmişlik düzeyi ve iş doyumu alt boyutlarının katılımcıların bağımsız karar verme süreçlerini değerlendirmelerine göre duygusal tükenmişlik, düşük kişiler arası başarı, duyarsızlaşma, içsel doyum ve dışsal doyum alt boyutlarında anlamlı farklılık bulunmuştur. Sonuçlara göre bağımsız karar verme süreci desteklenmedikçe tükenmişlik düzeyi, desteklendikçe ise iş doyumu artmaktadır. Basım ve Şeşen (2005) sosyal hizmet uzmanlarının daha fazla otonomi sahibi olmalarının tükenmişliği azaltacağını belirtmiştir. Ayrıca Waymer (1995) sosyal hizmet uzmanları ile yaptığı çalışmasında otonominin sosyal hizmet uzmalarının iş doyumlarını arttırdığını tespit etmiştir. Atamtürk (2010) uzmanların 
değerlendirmelerini özgürce yapmaları sonucunda iş doyumunun arttığını tespit etmiştir.

Katılımcıların tükenmişlik düzeyi ve iş doyumu alt boyutlarının mesleği isteyerek seçip seçmeme durumuna göre duygusal tükenmişlik, düşük kişisel başarı, duyarsızlaşma, içsel ve dışsal doyum düzeylerinde anlamlı bir farklılık bulunmuştur. Mesleği istemeyerek seçenlerin duygusal tükenmişlik, düşük kişisel başarı ve duyarsızlaşma düzeylerinin, mesleği isteyerek seçenlerin ise içsel ve dışsal doyum düzeylerinin daha yüksek olduğu bulunuştur.

\section{SONUÇ VE ÖNERILER}

Müracaatçının aldığı hizmetin kalitesi ve müracaatçının memnuniyeti doğrudan sosyal hizmet uzmanının memnuniyeti ile sağlanmaktadır. $\mathrm{Bu}$ nedenle tükenmişlikten en çok olan etkilenen meslekler arasında olan sosyal hizmet mesleğinde, sosyal hizmet uzmanlarının tükenmişlik yaşamalarına sebep olan koşulların ortadan kaldırılması ve uzmanların mesleğinin hevesle ve mutlu olarak icra etmesini sağlayan iş doyumunun arttırıması sosyal refah hizmetlerinin etkili bir şekilde uygulanmasında önemli bir rol oynamaktadır. Araştırma bulguları dikkate alınarak ileri araştırmalara yönelik öneriler olarak aşağıdaki öneriler sunulmuştur:

1. Kişisel özellikler ile mesleğin uyumu bireyin meslekte başarılı ve mutlu olması açısından etkili olacağı düşünülmektedir. Bunun için öncelikle meslek seçiminin bilinçli şekilde yapılması, bu sebeple tercih döneminde olan öğrencilere mesleğin gerekleri ve mesleğe uygun karakter özellikleri anlatılmalıdır.

2. Sosyal hizmet uzmanları mesleğin tanınmaması ve bundan ötürü görevinin anlaşılmamasından dolayı büyük sorun yaşamakta ve bu sorunlar zaman zaman mesleki çatışmalara sebep olmaktadır. Bu konuya çözüm olarak kamuoyunda sosyal hizmet mesleği ve bu mesleğin önemini anlatan çalışmalara yer verilmesi gerektiği önerilebilir.

3. Sosyal hizmet uzmanlarının vaka yoğunlukları bu yoğunluktan dolayıda müracaatçıları yeterli hizmet verememelerinden dolayı ortaya çıkan yetersizlik ve tükenmişlik duygularının önlenmesi için iş yüklerinin azaltıımasına yönelik tedbirlerinin alınmasının fayda sağlayacağı 
düşünülmektedir. Ayrıca karşılaşılan sorunlar arasında uzmanlar tarafından belirtilen ev incelemesinde karşılaşılan guvenlik problemlerinin giderilmesi yönünde tedbiler alınmasının önem taşıdığı görülmektedir.

4. Sosyal hizmet mesleğinde uzmanlar farklı müracaatçı grupları ve vaka türleri ile karşılaşılmakta ve bu konuda mevcut bilgileri yetersiz kalabilmektedir. Bu sebeple sıklıkla yeni bilgilere ihtiyaç duyulmaktadır. $\mathrm{Bu}$ konuda hizmet içi eğitimlerin arttırılması, süpervizyon sağlanması gerektiği düşünülmektedir.

5. Sosyal hizmet uzmanlarının yönetici ve iş arkadaşları ile olan ilişkilerinin olumlu şekilde kuvvetlenmesinin uzmanların performansı ve iş doyumu üzerinde önemli etkisi bulunmaktadır. Bu konuda kurum içi etkinliklerin arttırılmasın ilişkilerin kuvvetlenmesi açısından çözüm olabilir. Ayrıca yöneticilerin uzmanların bağımsız karar verme sürecini desteklemesi bu durumun kurum politikalarına yansıtılmasının uzmanların daha objektif kararlar vermesi açısından daha faydalı olacağı düşünülmektedir.

6. Çoğu zaman sosyal politikalar ve müracaatçı için gerekli olan kaynaklar müracaatçının sorunun gidermede yetersiz kalabilmektedir. Kurumda çalışan uzmanların çalıştıkları kurum ile ilgili politikaların oluşturulmasına katkıda bulunmasının bu konudaki eksikliği giderilmesini sağlayacağı düşünülmektedir.

\section{KAYNAKÇA}

Altunışık R, Çoşkun R, Bayraktaroğlu S, Yıldırım E. (2012). Sosyal Bilimlerde Araştırma Yöntemleri SPSS Uygulama (Yedinci baskı) Sakarya: Sakarya Yayıncılık

Anderson P. and Lundberg, J., (2008). Psychological Work Factors, Sector: Health And Social Work. Http://Journals.Plos.Org/Plosone/Article? ld =10.1371/ Journal.Pone.0152220. 18 Nisan 2018.

Arches J. (1991). Social Structure, Burnout, And Job Satisfaction, Social Work, 36 (3), 202206.

Atamtürk E. (2010). Aile Mahkemeleri Uygulamalarında Yaşanan Sorunların Aile Mahkemesi Uzmanlarının Tükenmişlik Düzeylerine Ve İş Doyumlarına Etkisi, Sosyal Bilimler 
Enstitüsü, Sosyal Hizmetler Anabilim Dalı, Yüksek Lisans Tezi, Ankara: Hacettepe Üniversitesi.

Basım H.N. ve Şeşen H. (2005) Çalışma Yaşamında Tükenmişlik: Sosyal Hizmet Uzmanları İle Hemşireler Üzerine Karşılaştırmalı Bir Çalışma, Toplum Ve Sosyal Hizmet, 16 (2), 57-69.

Baycan A. (1985). An Analysis Of Several Aspects Of Job Satisfaction Between Diffrent Occupational Groups, Sosyal Bilimler Enstitüsü, Psikoloji Anabilim Dalı, Yüksek Lisans Tezi, Boğaziçi Üniversitesi, İstanbul.

Bell H., Kulkarni, S., Dalton L. (2003) Organizational Prevention Of Vicarious Trauma. Families in Society, 84 (4), 463-470.

Bride B., Radey M., Figley C.R. (2007). Measuring Compassion Fatigue, Clinical Social Work Journal, 2007, 35, 155-163.

Calitz T,Roux A., Strydom H. (2014) Factors that affect social workers' job satisfaction, stress and burnout, Social Work/Maatskaplike Werk, 50(2), 153-169.

Can, A. (2016). SPSS ile Bilimsel Araştırma Sürecinde Nicel Veri Analizi, Pegem Akademi, Ankara.

Ceylan H., Gül N., Öksüz M. (2016). Sosyal Çalışmacılarda İş Doyumu Ve Tükenmişliğe Etki Eden Faktörlerin Sosyal Hizmet Alanlarına Göre Karşılaştırmalı İncelenmesi, Yalova Sosyal Bilimler Dergisi, 6 (11): 43-69.

ChoI G. (2010). The Influence Of Organızatıonal Characterıstıcs And Psychologıcal Empowerment On Secondary Traumatıc Stress Of Socıal Workers Workıng With Famıly Vıolence Or Sexual Assault Survivors, Doctor Of Philosophy İn Social Work, Urbana-Champaign, Urbana: College Of The University Of Illinois.

Ergin C. (1992). Doktor Ve Hemşirelerde Tükenmişlik Ve Maslach Tükenmişlik Ölçeğinin Uyarlanması. VII Ulusal Psikoloji Bilimsel Çalışmaları, Ankara: H.Ü. VII Ulusal Psikoloji Kongresi Düzenleme Kurulu Ve Türk Psikologlar Derneği Yayını.

Figley C.R. (1995). Compassion Fatigue: Coping With Secondary Traumatic Stress Disorder In Those Who Treat The Traumatized. New York, NY: Brunner/Mazel.

Işıkhan V. (2000). Sosyal hizmet uzmanlarının iş doyumu. Toplum ve Sosyal Hizmet, $1(10): 38-52$

İçağasıoğlu-Çoban, M. A., Özbesler, C. (2016). Hastanelerde Çalışan Sosyal Hizmet Uzmanlarında Tükenmişlik ve İş Doyumu. Başkent Üniversitesi Sağlık Bilimleri Fakültesi Dergisi-BÜSBID, 1(2), 90-109.

Karasar, N. (2002). Bilimsel Araştırma Yöntemleri. Ankara, Nobel Yayıncılık. 
Karasar, N. (2006). Bilimsel Araştırma Yöntemleri. Ankara, Nobel Yayıncılık.

Mackie P.F. (2005). Factors Associated With Job Satisfaction And Burnout Among Rural And Urban Social Workers, The Faculty Of The Graduate School Of Social Work, Doctorate Of Philosophy, University Of Denver.

Martin R. (1988) Social Work: An Introduction, Charles E. Merrill Publishing Company, A Bell And Howell Company

Maslach C. ve Jackson S.E. (1981). The Measurement Of Experienced Burnout, Journal Of Occupational Behaviour, 2 (2), 99-113.

Pecora P.J., Whittaker J.K., Maluccio A.N., Barth R.P. (2000). The Child Welfare Challenge: Policy, Practice, And Research, New York: Aldine Transaction.

Saakvitne K.W. and Pearlman L.A. (1996). Transforming The Pain: A Workbook On Vicarious Traumatization For Helping Professionals Who Work With Traumatized Clients. New York, NY, Norton.

Uğur, A. ve Erol, Z. (2015). Sosyal Çalışmacıların Çalışma Hayatında Karşılaştıkları Stres Faktörlerine Yönelik Kavramsal Bir Değerlendirme Ve Stres Yönetimi Müdahale Programları. Uluslararası Sosyal Araştırmalar Dergisi, 8(9), 987-998.

Uzun K. (2018). Sosyal Hizmet Uzmanlarının Mobbing (İş Yerinde Psikolojik Şiddet) Algısı Ve Tükenmişlik Ile Ilişkisinin Araştırılması: İstanbul Ili Örneği, Sosyal Hizmet Anabilim Dalı, İstanbul Üniversitesi, Yüksek Lisans Tezi, İstanbul.

Waymer R.W. (1995). A Study Of Work Autonomy And Job Satisfaction Of Social Workers İn Metropolitan Atlanta, Http: //Digitalcommons.Auctr.Edu/Cgi/ Viewcontent.Cgi? Article=2196\&Context=Dissertations, 17 Nisan 2017.

Williams M.B., Sommer J.F. (1995). Self-Care And The Vulnerable Therapist. İçinde: Stamm BH (Editörler), Secondary Traumatic Stress: Self-Care Issues For Clinicians, Researchers, And Educators. Lutherville, MD, Sidran Press.

Weiss R., Dawis G., England G., Lofquist L. (1967). Manual For The Minnesota Satisfaction Questionnaire, Minnesota Studies in Vocational Rehabilitation, XXII.

Yürür S. ve Sarıkaya M. (2011), Sosyal Çalışmacıların Sosyal Destek Algılarının Tükenmişliğe Etkisi, Ege Akademik Bakış Dergisi, 11 (4): 537-552. 